\title{
IGFs and IGF-Binding Proteins in the Synovial Fluid of Patients with Rheumatoid Arthritis and Osteoarthritis
}

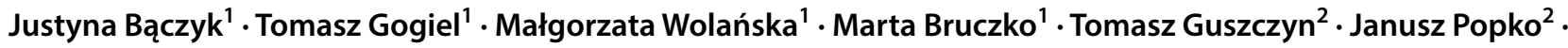 \\ Lech Romanowicz ${ }^{1}$
}

Accepted: 5 March 2019 / Published online: 8 March 2019

(c) The Author(s) 2019

\begin{abstract}
The progressive damage of human articular cartilage is associated with loss of integrity of its extracellular matrix components. Their metabolism is under the control of cytokines produced locally. It is known that peptide growth factors stimulate chondrocytes to synthesize matrix components, and other cytokines, such as interleukins, promote their catabolism by stimulation of chondrocytes to the production of enzymes degrading components of cartilage. The aim of this study was evaluation the presence of inulin-like growth factors (IGFs) in synovial fluid and blood serum of patients with rheumatoid arthritis and osteoarthritis and their binding proteins and matrix metalloproteinases that regulate their bioavailability using Western Immunoblot, ELISA test and zymography technique. The results showed that both IGFs were present, first of all, in the form of high molecular complexes with their specific binding proteins. In this way those proteins prolonged growth factors' half-life but suppressed their bioavailability for receptors and action on target cells. Low content of free IGF-I indicated limitation of its anabolic influence on cartilage metabolism of patients with both diseases.
\end{abstract}

Keywords Insulin-like growth factor $\cdot$ Insulin-like growth factor-binding protein $\cdot$ Matrix metalloproteinase $\cdot$ Synovial fluid $\cdot$ Rheumatoid arthritis $\cdot$ Osteoarthritis

\section{Introduction}

The metabolism of extracellular matrix components is under control of locally produced cytokines. It is known that insulin-like growth factors (IGFs) and other peptide growth factors stimulate cartilage chondrocytes to synthesize matrix components. Other cytokines such as tumor necrosis factor (TNF) or some interleukins (IL-1, IL-6) inhibit the synthesis of these components and at the same time stimulate chondrocytes to produce matrix metalloproteinases (MMPs) (Malejczyk 2001).

The imbalance between the anabolic and catabolic effects of cytokines can cause degenerative changes in the cartilage. In some cases, damaged cartilage can be regenerated to form the so called fibrocartilage. This type of cartilage does not

Justyna Bączyk

justyna.baczyk@umb.edu.pl

1 Department of Medical Biochemistry, Medical University of Białystok, Mickiewicza 2C, 15-089 Białystok, Poland

2 The Department of Pediatric Orthopedics and Traumatology, Medical University of Białystok, Białystok, Poland have the strength and resilience of hyaline cartilage. It is less resistant to load and trauma (Malejczyk 2001; Dziak 2001).

The damage and expenditure of the articular cartilage is characteristic of modern times. The main cause of early expenditure of the cartilage is the sum of overload and microtrauma due to obesity, sedentary lifestyle, many systemic diseases or excessive mechanical load of the joints or their instability (Dziak 2001).

In different pathological conditions, the levels of proinflammatory cytokines, extracellular matrix metalloproteinases, cathepsins, glycosidases or chondroitinases are significantly increased in the synovial fluid, independently of the pathogen. The content of acute phase proteins produced by chondrocytes and leukocytes increases. Especially in the early stages of illness, catabolic processes prevail, resulting in damage to the hyaline cartilage (Caglič et al. 2010).

The effects of IGFs are well known and with a very broad spectrum of activity. In physiological concentrations, IGF-I and IGF-II induce mitogenic effects mostly. They stimulate the synthesis of collagen and other extracellular matrix components (Herchenhan et al. 2015; Józefiak et al. 2008). They also enhance the production of enzymes that are able to 
degrade extracellular matrix components. In this way these peptide growth factors control the content of the extracellular matrix by taking part in both synthesis and degradation of several proteins (Józefiak et al. 2008; Puche and CastillaCortàzar 2012). Apart from strong mitogenic activity, IGF-I participates in the regulation of growth, differentiation and chemotaxis of normal and neoplastic cells (Puche and Castilla-Cortàzar 2012; Suwała et al. 2010; Collett-Solberg and Cohen 2000; Martin et al. 2000; Rosenzweig and Atreya 2010).

In blood plasma and tissues, IGF is present mainly in the form of complexes with specific proteins. There are at least eight IGF binding proteins (IGFBP), characterized by a varied degree of affinity for IGFs and modifying their bioavailability (Józefiak et al. 2008; Puche and Castilla-Cortàzar 2012; Collett-Solberg and Cohen 2000; Forbes et al. 2012). Over $90 \%$ of circulating IGFs in plasma are bound to IGFBP-3, and to the acid-labile subunit (ALS) in the form of the macromolecular complex with a molecular weight of about $150 \mathrm{kDa}$. Such a complex extends the half-life of IGF-I from several minutes to even $15 \mathrm{~h}$. IGFBP-3 is produced mainly by the Kupffer cells of the liver. The rest of the IGFs are present in the form of a complex with other binding proteins, with a molecular weight of about $40-50 \mathrm{kDa}$. Only a small part of that growth factor is present in a free active form, and can bind to its specific receptor on the surface of target cells (Józefiak et al. 2008; Puche and Castilla-Cortàzar 2012; Suwała et al. 2010; Forbes et al. 2012; De Benedetti et al. 2001).

The characterization of IGF-I, IGF-II, IGF-BPs and matrix metalloproteinases in the synovial fluid provides information necessary to understand the modulation of synovial fluid metabolism in inflammatory processes affecting the knee joints. Therefore, we decided to determine the concentration of IGF-I and the expression of both IGFs, their binding proteins, IGFBP-1 and IGFBP-3, and to evaluate gelatinolytic activity in articular exudates and blood serum of patients with rheumatoid arthritis (RA) and osteoarthritis (OA).

\section{Materials and Methods}

All the protocols in the current study involving human patients were accepted by the Committee for Ethics and Supervision of Human and Animal Research of the Medical University of Białystok, and were conducted in accordance with the Declaration of Helsinki.

\section{Patients and Sample Collection}

The research was performed on a group of 25 patients, including 15 ( 8 males and 7 females, aged between 40 and
45 years) with rheumatoid arthritis, classified according to the American College of Rheumatology (formerly, the American Rheumatism Association) (Arnett et al. 1988) and 10 (4 males and 6 females, aged between 75 and 80 years) with osteoarthritis of the knee grade 2 or 3 according to the Kellgren and Lawrence classification (Wright 2014). After their first admission to hospital, the synovial fluid was collected during routine diagnostic or therapeutic arthrocentesis. Blood was also obtained in a small volume of $5 \mathrm{ml}$.

\section{Sample Processing}

Blood samples were collected into glass test tubes. The retracted clot was removed by centrifugation at room temperature. The serum was collected and stored at $-70{ }^{\circ} \mathrm{C}$ until further use.

The samples of exudates were taken from the knee joints of both groups of patients during arthrocentesis performed for diagnostic or therapeutic purposes. All samples of the synovial fluid were centrifuged. The supernatants were collected and stored at $-70{ }^{\circ} \mathrm{C}$ until further use.

\section{Sodium Dodecyl Sulphate/Polyacrylamide Gel Electrophoresis (SDS-PAGE)}

SDS-PAGE was performed according to the Laemmli method (Laemmli 1970) with the use of molecular weight standards (Bio-Rad).

\section{Gelatin Zymography}

In order to detect metalloproteinase activity, gelatin zymography was performed by the method described by Unemori and Werb (1989). The serum and synovial fluids were mixed with a Laemmli sample buffer (Laemmli 1970) containing $3.0 \%$ SDS (without reducing agent). The same amounts of protein $(10 \mu \mathrm{g})$ were electrophoresed on $7.5 \%$ polyacrylamide gel containing gelatin in a concentration of $1 \mathrm{mg} / \mathrm{ml}$.

After electrophoresis, the gels were submitted to extraction of SDS with $0.25 \%$ Triton X-100 $(2 \times 15 \mathrm{~min})$ at room temperature and then transferred into $0.05 \mathrm{M}$ Tris/ $\mathrm{HCl}, \mathrm{pH}$ 7.5, containing $10 \mathrm{mmol} / \mathrm{l} \mathrm{CaCl} 2,1 \mu \mathrm{mol} / 1 \mathrm{ZnCl}_{2}, 1 \%$ Triton $\mathrm{X}-100$ and $0.02 \% \mathrm{NaN}_{3}$. The gel was then incubated for $16 \mathrm{~h}$ at $37^{\circ} \mathrm{C}$.

After incubation, the gels were stained with $1 \%$ Coomassie Brilliant Blue R-250 for $14 \mathrm{~h}$ and distained with $10 \%$ acetic acid in $25 \%$ isopropanol. The position of gelatindegrading enzymes present in the serum and synovial fluid became visible as clear zones on a blue background. A representative zymogram is presented in this paper. 


\section{IGF-I Content}

The content of IGF-I in the study materials was determined with quantitative assay, Human IGF-I Quantikine ELISA Kit provided by R\&D Systems according to the manufacturer's instruction. Free IGF-I was measured using the modified ELISA Kit procedure. For this purpose, synovial fluid samples were directly added on the plate without prior mixing with a reagent releasing IGF-I from complexes (provided by the manufacturer in ELISA Kit).

\section{Western Blot Analysis}

After SDS-PAGE, the gels were allowed to equilibrate for $5 \mathrm{~min}$ in $25 \mathrm{mmol} / \mathrm{l}$ Tris, $0.2 \mathrm{~mol} / \mathrm{l}$ glycine in $20 \%(\mathrm{v} / \mathrm{v})$ methanol for $5 \mathrm{~min}$. The protein was transferred to $0.2 \mu \mathrm{m}$ pore-sized nitrocellulose membranes at $100 \mathrm{~mA}$ for $1 \mathrm{~h}$ using Bio-Rad Mini-Protean 3 apparatus. The membranes were incubated with specific primary monoclonal antibodies against investigated proteins diluted 1:500 in 5\% dried milk in TBS-T $(20 \mathrm{mmol} / \mathrm{l}$ Tris- $\mathrm{HCl}$ buffer, $\mathrm{pH} 7.4$, containing $150 \mathrm{mmol} / \mathrm{l} \mathrm{NaCl}$ and $0.05 \%$ Tween 20 ) for $1 \mathrm{~h}$, followed by alkaline phosphatase-conjugated secondary antibody against mouse IgG, added at a concentration of 1:2000 in TBS-T. The incubation was continued for $30 \mathrm{~min}$ with slow mixing. Then the nitrocellulose membrane was washed with TBS-T buffer (5 times for $5 \mathrm{~min}$ ) and submitted to the action of Sigma - Fast BCIP/NBT reagent for band visualization.

\section{Detection of IGF-I, IGF-II, IGFBP-1 and IGFBP-3}

Both insulin-like growth factors (IGF-I and IGF-II) and binding proteins (IGFBP-1 and IGFBP-3) were detected by Western immunoblot analysis with the use of the respective specific primary monoclonal antibody (Sigma-Aldrich). Representative blots have been shown.

\section{Determination of Protein Concentration}

Protein concentration in the serum and synovial fluid samples was measured by Bradford method (Bradford 1976) and biuret method (Freeman et al. 1961).

\section{Statistical Analysis}

The mean values for IGF-I concentration \pm standard deviations (S.D.) were calculated. The results were submitted to statistical analysis with Student's " $t$ " test, accepting $p<0.05$ as significant.

\section{Results and Discussion}

Western immunoblot, shown in Fig. 1, indicated the presence of IGF-I in the blood serum and synovial fluid of patients with RA and OA. After electrophoresis in nonreducing conditions IGF-I was present only in macromolecular complexes visible in the form of a broad band weakly penetrating the separating gel (Fig. 1a). Two smaller bands appeared after the reduction in disulphide bonds (Fig. 1b). One of them (the more intensive band) with a molecular weight of about $40 \mathrm{kDa}$, might be an IGF-I protein complex. The less intensive band of molecular weight of approximately $7.5 \mathrm{kDa}$ corresponded to free IGF-I. All the samples gave similar results (Fig. 1).

The expression of IGFBP-1 in the blood serum and synovial fluid of patients with RA and OA determined by Western Immunoblot with the use of specific anti-IGFBP-1 antibody is shown in Fig. 2. After electrophoresis without $\beta$-mercaptoethanol as a reducing agent, the binding protein IGFBP-1 was present only in the form of large complexes found on the top of gel in all the investigated fluids (Fig. 2a). These complexes might contain polymers of IGFBP-1 or its connection to ALS subunit, and even less specific proteins, e.g. cell membrane proteins (Puche and Castilla-Cortàzar 2012; Masnikosa et al. 2009). After the reduction in disulfide bonds, followed by decay of the complex, a new wide band of lower molecular weight (about $30 \mathrm{kDa}$ ) appeared, corresponding to a molecular weight of IGF-I or IGF-II connected to BP-1, and a few bands in the range of $65-120 \mathrm{kDa}$ (Fig. 2b). There was no evidence for the presence of the free form of IGFBP-1. Both kinds of fluids taken from patients with RA and OA showed similar results (Fig. 2).

Figure 3 shows the presence of IGFBP-3 in the serum and synovial fluid of patients with RA and OA. The results obtained by Western Immunoblot using a specific antibody against IGFBP-3 were very similar for synovial fluid and serum, irrespective of disease. Visible macromolecular complexes weakly penetrated the gel, indicating the presence of IGFBP-3 in the blood serum and synovial fluid of patients with RA and OA (Fig. 3a). Probably it was an IGF/IGFBP-3/ALS complex.

Under the action of $\beta$-mercaptoethanol as a reducing agent, the high molecular complex of about $170 \mathrm{kDa}$ disappeared and there appeared a band corresponding to the molecular weight of $35 \mathrm{kDa}$. Such a mass was characteristic of the IGF-I and IGFBP-3 complexes. Interestingly, complexes with higher molecular weights, ranging from 55 to $120 \mathrm{kDa}$, were observed (Fig. 3b), but they were difficult to interpret. We could not exclude that these complexes might contain other IGF binding proteins (more than one). However, free binding protein (BP-3) could 
Fig. 1 Western immunoblot analysis for IGF-I in non-reducing conditions (a) and reducing conditions (b). Lanes: 1 serum of RA patient, 2 synovial fluid of RA patient, 3 serum of OA patient, 4 synovial fluid of OA patient. The same amount of protein $(10 \mu \mathrm{g})$ was used in each lane

Fig. 2 Western immunoblot analysis for IGFBP-1 in non-reducing conditions (a) and reducing (b) conditions. Lanes: 1 serum of RA patient, 2 synovial fluid of RA patient, 3 serum of OA patient, 4 synovial fluid of OA patient. The same amount of protein $(10 \mu \mathrm{g})$ was used in each lane
A

B

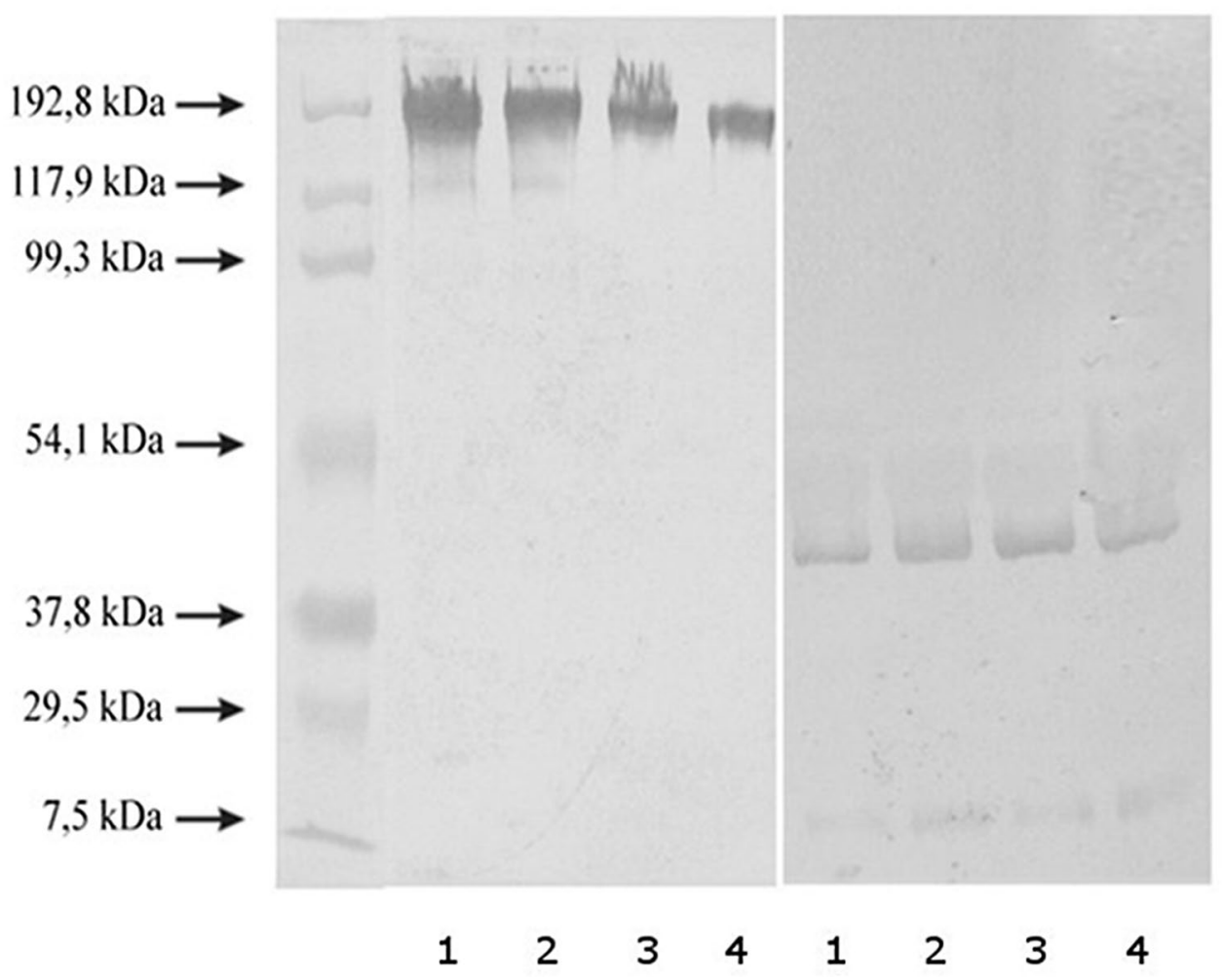

A

B

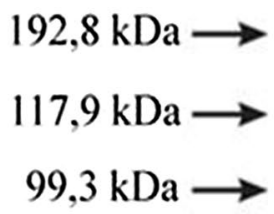

$54,1 \mathrm{kDa} \longrightarrow$

$37,8 \mathrm{kDa} \longrightarrow$

$29,5 \mathrm{kDa} \longrightarrow$

$7,5 \mathrm{kDa} \longrightarrow$ 
Fig. 3 Western immunoblot analysis for IGFBP-3 in nonreducing (a) and reducing (b) conditions. Lanes: 1 serum of RA patient, 2 synovial fluid of RA patient, 3 serum of OA patient, 4 synovial fluid of OA patient. The same amount of protein $(10 \mu \mathrm{g})$ was applied in each lane
A

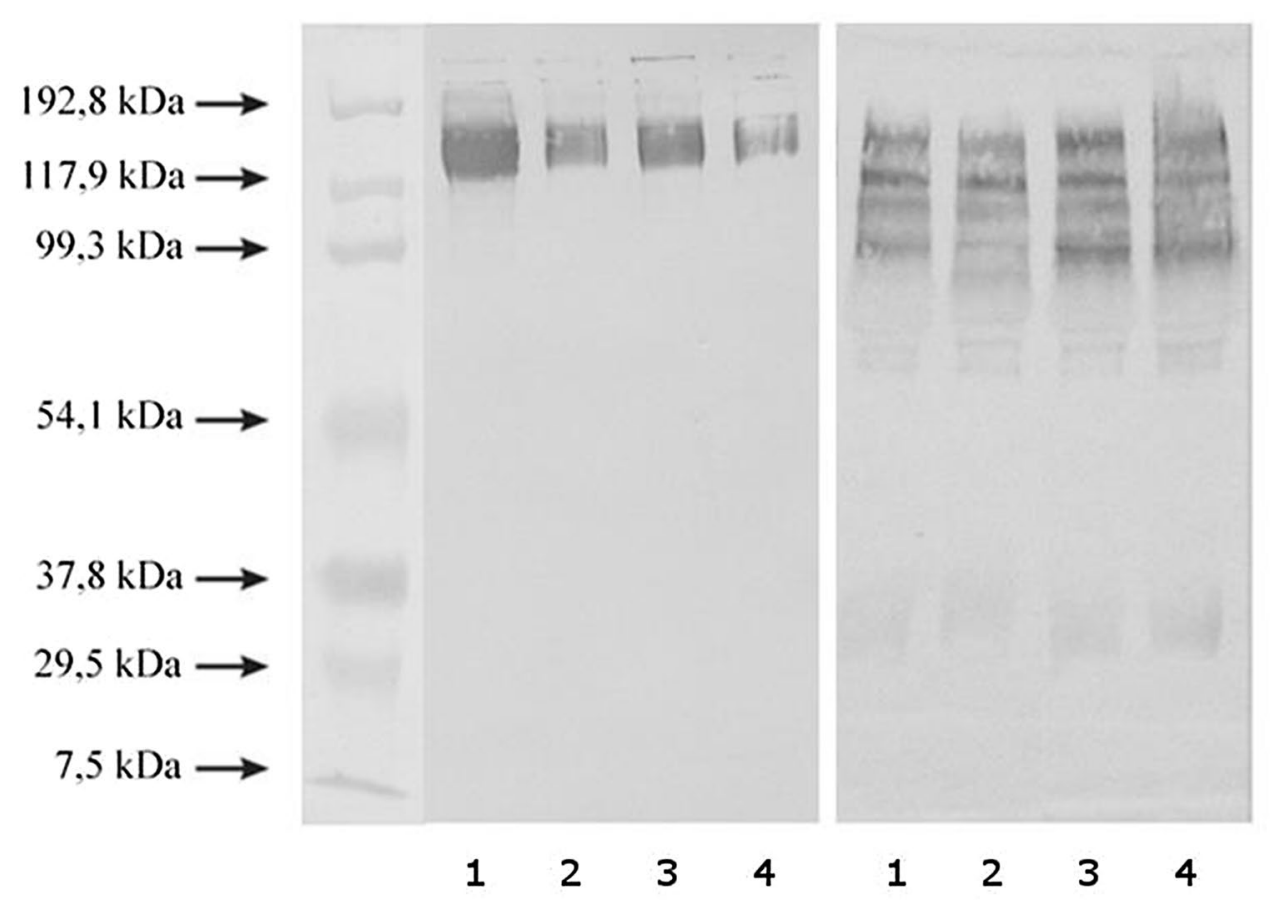

not be detected, regardless of electrophoretic separation and a reducing agent used (Fig. 3). The binding protein IGFBP-3 was considered the main factor protecting IGF-I against the proteolytic degradation (Beliozon et al. 2007; Mong et al. 2009). Over $90 \%$ of the IGF found in the body was associated with IGFBP-3 and the acid-labile molecule (Puche and Castilla-Cortàzar 2012). In pathological states, the increased concentration of IGF-I was accompanied by a high content of its binding protein, IGFBP-3 (Tavera et al. 1996; de Sousa et al. 2014; Denko et al. 1996; Albornoz Torrente and Forriol 2012; Matsumoto et al. 1996; Pagura et al. 2005; Schmidt et al. 2006).

In our research we indicated the presence of insulinlike growth factor type II (IGF-II) in the synovial fluid and serum of patients with RA and OA. Figure 4 shows that IGF-II contained in the serum and synovial fluid of both RA and OA patients penetrated in one visible band (about $170 \mathrm{kDa}$ ) with similar intensity, during electrophoresis in non-reducing conditions (Fig. 4a). Like IGF-I, also IGF-II formed macromolecular complexes with a variety of proteins, such as binding proteins and/or ALS subunit. The use of $\beta$-mercaptoethanol for the reduction in disulphide bonds resulted in dissociation of high molecular complex into components with lower molecular weight, corresponding to approximately $30 \mathrm{kDa}, 54 \mathrm{kDa}, 99 \mathrm{kDa}$, and $120 \mathrm{kDa}$ (Fig. 4b). The presence of a free form of IGF-II was not observed. No differences were found between RA and OA serum as well between RA and OA synovial fluid (Fig. 4). Patients with osteoarthritis and rheumatoid arthritis contained IGF-II in the synovial fluid at a similar level as healthy controls (Tavera et al. 1996).

The comparison of Western blot analysis for IGF-I, IGFII and their binding proteins, IGFBP-1 and IGFBP-3, indicated that the growth factors studied were present in high molecular complexes in the synovial fluid and blood serum of patients with RA and OA. Electrophoresis in non-reducing conditions showed a broad band of about $150 \mathrm{kDa}$ for all the investigated proteins. The complex contained one of the growth factors, IGF-I or IGF-II, one of the binding proteins, IGFBP-1 or IGFBP-3, and the acid-labile subunit.

Proteolysis, especially of the extracellular matrix, might be assessed by zymography, the technique used to compare the presence of collagenolytic/gelatinolytic enzymes in biological fluids, including synovial fluid. The zymogram shown in Fig. 5 indicated the presence of gelatinases in the serum and synovial fluid of patients with RA and OA. Gelatinase activity in synovial fluids (lane 2 and 4) was much more intensive, as compared to the corresponding serum (Fig. 5, lane 1 and 3). Similar findings were described by Giannelli and co-workers (Giannelli et al. 2004).

The band with a molecular weight of about $62 \mathrm{kDa}$ corresponded to the active form of MMP-2 (A) which was present only in the synovial fluid of RA patient (Fig. 5, lane 2). The intensive band with a molecular weight of $72 \mathrm{kDa}(\mathrm{B})$ suggested the presence of a latent form of the enzyme. This form was visible in the serum and also in the synovial fluid of all the study patients (Fig. 5, lane 1-4). The increased activity of MMP-2 was detected in the synovial fluids in 
Fig. 4 Western immunoblot analysis for IGF-II in nonreducing conditions (a) and reducing conditions (b). Lanes: 1 serum of RA patient, 2 synovial fluid of RA patient, 3 serum of OA patient, 4 synovial fluid of OA patient. The same amount of protein $(10 \mu \mathrm{g})$ was applied in each lane
A

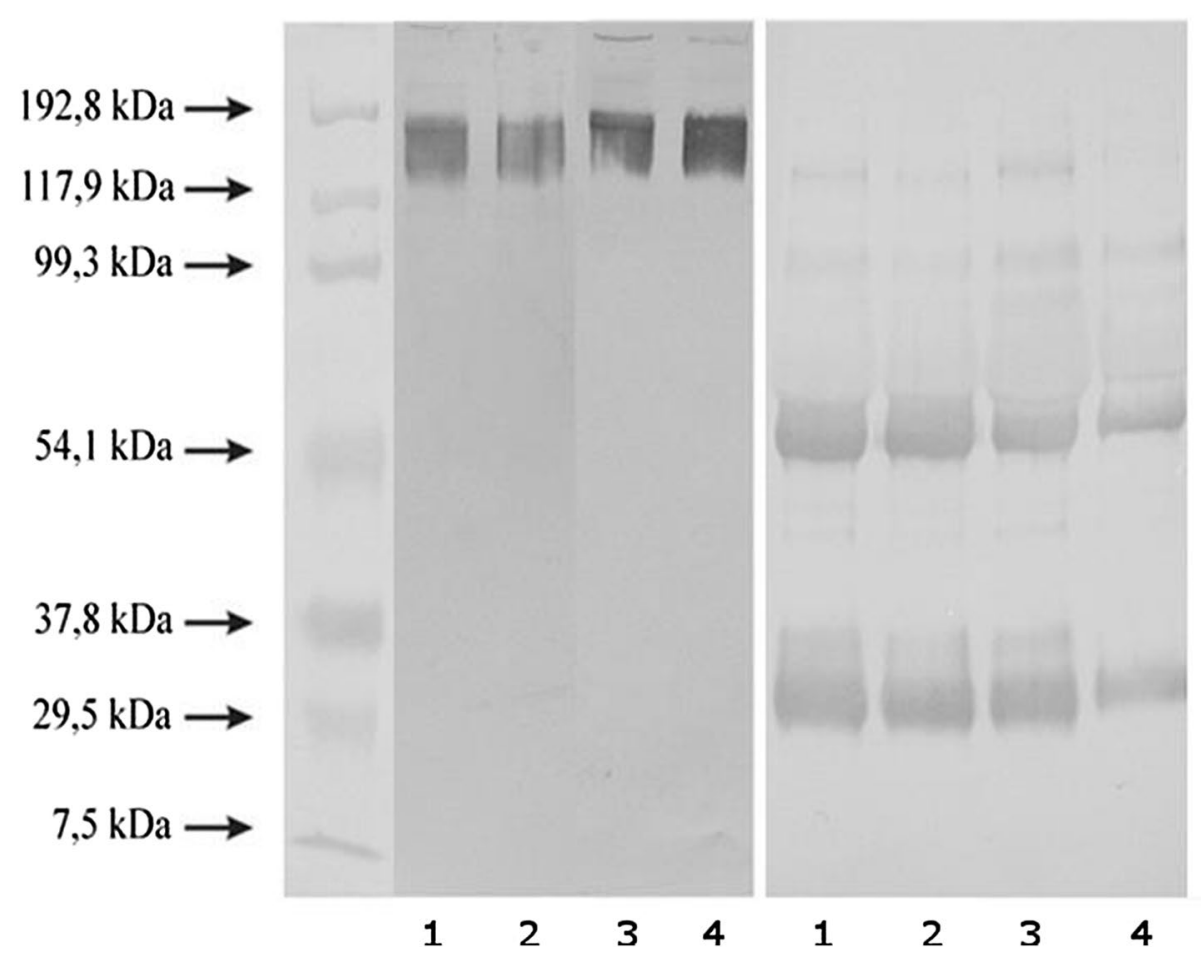

comparison to the respective blood serum. Other bands corresponding to molecular weights of $82 \mathrm{kDa}(\mathrm{C})$ and $92 \mathrm{kDa}$ (D) showed the presence of active and latent forms of MMP9, respectively. The active form of MMP-9 (C) was present in all study materials. Both synovial fluids (Fig. 5, lane 2 and 4) demonstrated the light band corresponding to the latent form of MMP-9 (D). It is believed that MMP-9 is involved in the degradation of the basic substance of the cartilage (Hrycaj and Łącki 2002).

Bands located on top of the gel corresponding to a molecular weight higher than $100 \mathrm{kDa}(\mathrm{E})$ were visible in all study materials. This phenomenon suggested the presence of complexes of collagenolytic/gelatinolytic enzymes with other extracellular proteins. The results showed that the total collagenolytic/gelatinolytic activity was higher in the synovial fluid as compared to the serum of patients with RA and OA. In particular, the synovial fluid of RA patients (Fig. 5, lane 2) revealed the highest activity of gelatinases in comparison to all other materials. This proteolytic activity was more intense in all the materials obtained from both groups of patients in comparison to the respective fluid of young persons with PTD described in our earlier paper (Guszczyn et al. 2009).

These findings correlated with our assessment of the content of the small molecular products of proteolysis. The content of oligopeptides might reflect the degree of tissue destruction or severity of lesions occurring in the joints, especially in the initial stages of disease. In order to determine the content of low molecular protein degradation products in the synovial fluid, we measured protein concentration in all samples by the biuret method and the method of Bradford. The biuret method was used to determine the concentration of short peptides (starting from tripeptide), as well as other peptides and proteins with longer chains. The Bradford method (Bradford 1976) enabled the measurement of peptides having a molecular weight in excess of about $3000 \mathrm{Da}$ (Sapan et al. 1999). The comparison of the results obtained by both methods helped estimate the amount of oligopeptides. These products were formed by the action of extracellular matrix metalloproteinases and other endopeptidase "cutting" long polypeptide chains into shorter pieces (Bańkowski 2016). Our results showed that in both cases the synovial fluid of RA and OA patients contained large amounts of oligopeptides, more than $50 \%$ of total protein content (RA-almost 57\%, OA-about 63\%). Such a high content of short peptides in the synovial fluid of both cases indicated enhanced destruction of joint cartilage. In physiological conditions, extracellular matrix degradation products were absorbed by neighbor cells and were cleaved in lysosomes to free amino acids (Bańkowski 2016). Prolonged stay of the extracellular protein parts in the synovial fluid might suggest their weaker endocytosis by chondrocytes. It could not be excluded that our results could also be affected by the increase in the content of biologically active short peptides released in the course of inflammation, such as kinins (Jin et al. 2003). 


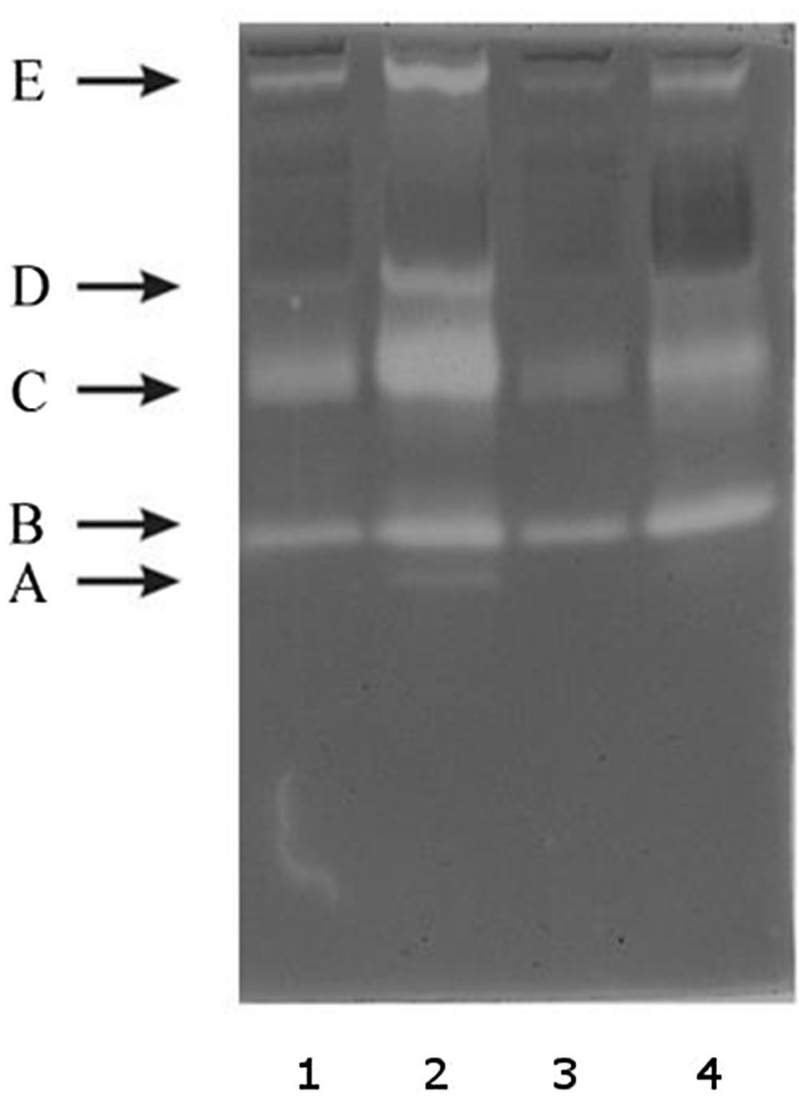

Fig. 5 Gelatinolytic activity of serum and synovial fluid of RA and OA patients. Lanes: 1 serum of RA patient, 2 synovial fluid of RA patient, 3 serum of OA patient, 4 synovial fluid of OA patient. The same amount of protein $(10 \mu \mathrm{g})$ was applied in each lane

The proteolytic activity of both MMP-2 and MMP-9 was regulated by interaction with three specific tissue inhibitors of metalloproteinases, TIMP-1, TIMP-2 and TIMP-4 (Zaga-Clavellina et al. 2011). Heard and colleagues (Heard et al. 2012) showed that the content of TIMP-1, TIMP-2 and TIMP-4 in the synovial fluid of patients with OA did not differ in comparison to healthy persons. The only significant difference was the increased TIMP-2 content in the synovial fluid of patients with RA (Heard et al. 2012). Giannelli and co-workers (Giannelli et al. 2004) indicated higher concentrations of TIMP-1 and TIMP-2 in the synovial fluid than in the blood serum of patients with RA (Giannelli et al. 2004). Al-Sebaie and colleagues (Al-Sebaie et al. 2003) also reported a higher TIMP- 1 content in RA synovial fluid than in blood serum. They also showed similar results for patients with OA (Al-Sebaie et al. 2003). Yoshihara and co-workers (Yoshihara et al. 2000) compared TIMP-1 and TIMP-2 concentration in the synovial fluid of patients with RA to those with OA. Only TIMP-1 content was significantly increased in RA synovial fluid (Yoshihara et al. 2000). Su and colleagues (Su et al. 1999) investigated the expression of

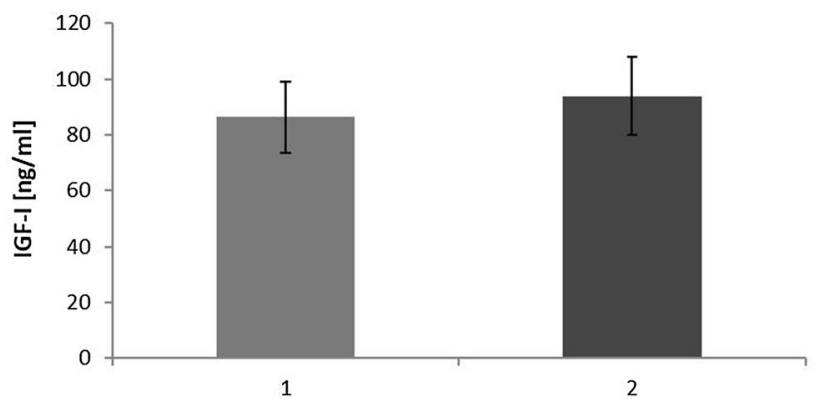

Fig. 6 The concentration of IGF-I in the blood sera of 1 patients with RA, 2 patients with $\mathrm{OA}$

TIMPs in osteoarthritic joints. The level of tissue inhibitor of matrix metalloproteinase-1 was elevated in human OA synovium without major changes in the TIMP-2 RNA levels ( $\mathrm{Su}$ et al. 1999). High contents of gelatinases could be responsible for the proteolysis of cartilage extracellular matrix components, while high amounts of TIMPs could be involved in the gelatinase activation process and in the regulation of MMP activity, thus contributing to cartilage damage (Giannelli et al. 2004). The activity of matrix metalloproteinases was also regulated, at least in part by peptide growth factors, including IGF-I (Józefiak et al. 2008; Pagura et al. 2005; Schmidt et al. 2006; Giannelli et al. 2004). On the other hand, some matrix metalloproteinases were involved in the degradation of IGF-binding proteins and affect the action of peptide growth factor (Józefiak et al. 2008; Sapan et al. 1999; Bańkowski 2016; Jin et al. 2003; Bączyk et al. 2016).

Figure 6 shows the total content of IGF-I in the blood serum of patients with RA and OA measured by ELISA test. The serum of these patients contained similar amounts of IGF-I (approximately 90 nanograms $/ \mathrm{ml}$ ).

Insulin-like growth factors and their specific binding proteins plays an important role in the homeostasis of cartilage. They stimulate the synthesis of proteoglycans, collagen type II and integrin receptors in that tissue. In vitro studies have demonstrated a stimulating effect of IGF-I on the synthesis of proteoglycans through the stimulation of chondrogenesis (Starkman et al. 2005).

The concentrations of insulin-like growth factor I in the synovial fluid of patients with RA and OA are presented in Fig. 7. The concentration of IGF-I in RA samples was lower than $60 \mathrm{ng} / \mathrm{ml}$, whereas in OA samples it was about $90 \mathrm{ng} /$ $\mathrm{ml}$. Thus, the IGF-I concentration in OA synovial fluid was higher by almost $40 \%$ than in the exudates of RA patients (Fig. 7).

The synovial fluid of RA patients contained only $66 \%$ of IGF-I in comparison to their blood serum. Interestingly, OA samples of exudates had nearly the same content of this growth factor as in blood serum (approximately $90 \mathrm{ng} / \mathrm{ml}$ ), (Fig. 7). 


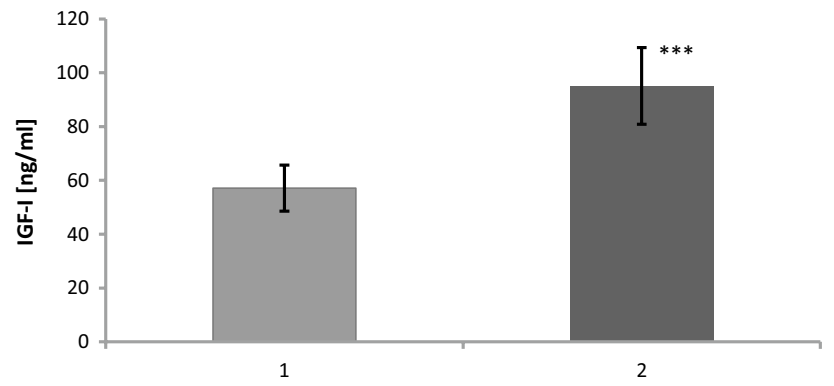

Fig. 7 The concentration of IGF-I in the synovial fluid of 1 patients with RA, 2 patients with $\mathrm{OA}$; *** $p<0.001$

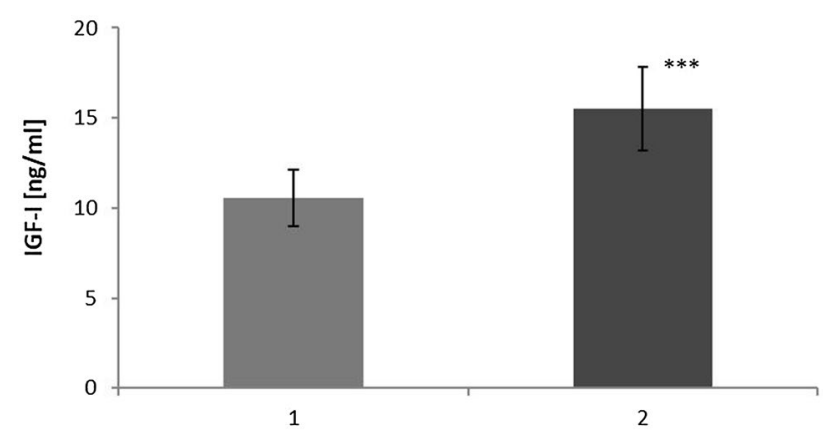

Fig. 8 The concentration of free IGF-I in the synovial fluid of 1 patients with RA, 2 patients with OA; ***p $<0.001$

Figure 8 shows the concentration of free IGF-I in the synovial fluid of RA and OA patients measured by modified ELISA test. In all the synovial fluid samples this peptide growth factor was present in small quantities. The concetration of free IGF-I in the synovial fluid of patients with RA was about $11 \mathrm{ng} / \mathrm{ml}$, and was approximately $40 \%$ higher in OA patients (Fig. 8). It was in agreement with Western Immunoblot analysis showing the presence of a weak band of molecular weight (approximately $7.5 \mathrm{kDa}$ ), which corresponded to the free form of IGF-I. A significantly higher concentration of free IGF-I in the synovial fluid of young patients with post-traumatic knee damage was reported earlier (Guszczyn et al. 2009).

The comparison of the concetration of free IGF-I in the synovial fluid of patients with RA and OA to its total content is shown in Fig. 9. Free IGF-I constituted only approximately $19 \%$ of its total content in the synovial fluid of RA patients. The percentage of free IGF-I in OA samples was insignificantly lower - about $16 \%$ (Fig. 9).

Table 1 demonstrates the concentration of IGF-I (total and free form content, and percentage of free form) in the blood serum and synovial fluid of patients with PTD, RA and OA measured by ELISA test. We chose patients with PTD as an example of young persons and inflammation

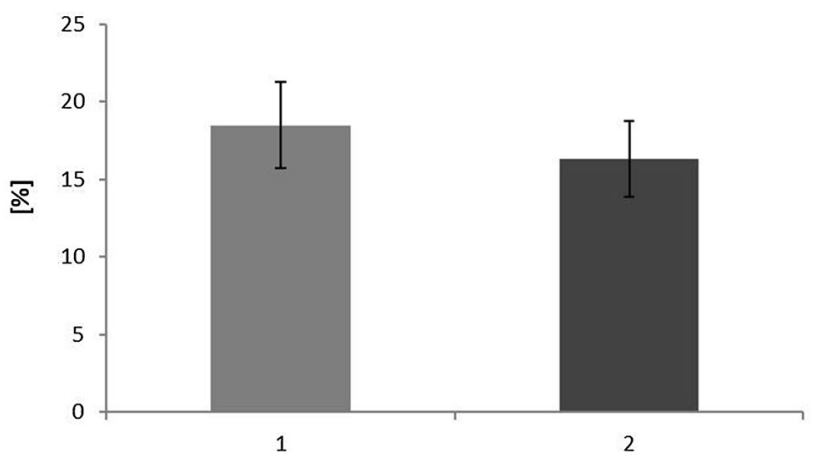

Fig. 9 The percentage of free IGF-I in the synovial fluid of 1 people with RA, 2 people with OA

Table 1 The concentration of IGF-I in blood serum and synovial fluids (SF) of patients with PTD (Guszczyn et al. 2009), RA and OA

\begin{tabular}{|c|c|c|c|c|}
\hline & \multicolumn{2}{|c|}{ IGF-I [ng/ml] } & \multirow{2}{*}{$\begin{array}{l}\text { Free IGF-I }[\mathrm{ng} / \mathrm{ml}] \\
\text { SF }\end{array}$} & \multirow{2}{*}{$\begin{array}{l}\text { The percentage } \\
\text { of free IGF-I } \\
\text { SF }\end{array}$} \\
\hline & Serum & SF & & \\
\hline \multicolumn{5}{|c|}{ Young patients } \\
\hline PTD & $327 \pm 49$ & $178 \pm 27$ & $25.9 \pm 3.9$ & $14.6 \pm 2.2$ \\
\hline \multicolumn{5}{|c|}{ Adult patients } \\
\hline RA & $86 \pm 13^{\mathrm{a}}$ & $57 \pm 9^{\mathrm{a}}$ & $10.6 \pm 1.6^{\mathrm{a}}$ & $18.5 \pm 2.8^{\mathrm{a}}$ \\
\hline OA & $94 \pm 14^{\mathrm{a}}$ & $95 \pm 14^{\mathrm{a}, \mathrm{b}}$ & $15.5 \pm 2.3^{\mathrm{a}, \mathrm{b}}$ & $16.3 \pm 2.5$ \\
\hline
\end{tabular}

${ }^{\mathrm{a}} p<0.001$ for comparison of RA or OA to PTD

${ }^{\mathrm{b}} p<0.001$ for comparison of OA to RA

of different etiology. Some of the results were presented earlier (Guszczyn et al. 2009). We compared ELISA test results of adult patients with RA and OA with young patients with PTD. Both materials obtained from adults contained distinctly less IGF-I (total and free form). Only the percentage of the free form of IGF-I in the synovial fluid was significantly higher in adult patients with RA (almost 19\%) in comparison to young patients with PTD. In contrast, the exudates of patients with $\mathrm{OA}$ were characterized by a similar percentage of free IGF-I as in young patients (Table 1).

The equilibrium between the formation and degradation of cartilage is fundamental to keep integrity of this tissue. Many pathological conditions, including various forms of arthritis, disrupt this balance, leading to an increase in the catabolic processes. Although the pathogenesis of these diseases may differ, metabolic consequences can be similar. Anyway, they are always associated with a progressive loss of cartilage or its reconstruction. The processes of remodeling and destruction of cartilage involve the action of proteolytic enzymes, mainly matrix metalloproteinases (Hrycaj and Łącki 2002). 


\section{Conclusion}

In the synovial fluid of patients with RA and OA, IGF-I is predominantly present in the form of macromolecular complexes which, under the action of a reducing agent, release only small amounts of a free form of IGF-I. Such a small amount of free IGF in the synovial fluids of adult patients in particular suggests limitation in its anabolic effects since only the free growth factor interacts with its specific receptor on the cell surface. Higher content of low molecular peptides and higher activity of matrix metalloproteinases indicates prevalence of degradation processes in the synovial fluid of patients with RA and OA, which may be the reason for much lower content of IGF-I both in a free form and in high molecular complexes.

\section{Compliance with Ethical Standards}

Conflict of interest All authors declare that they have no conflict of interest.

Informed Consent Informed consent was obtained from all individual participants included in the study.

Open Access This article is distributed under the terms of the Creative Commons Attribution 4.0 International License (http://creativeco mmons.org/licenses/by/4.0/), which permits unrestricted use, distribution, and reproduction in any medium, provided you give appropriate credit to the original author(s) and the source, provide a link to the Creative Commons license, and indicate if changes were made.

\section{References}

Al-Sebaie MA, Al-Yasaky AZ, Assaf NY, Mahdy MM, Elwan N (2003) Serum and synovial fluid levels of MMP-3 and TIMP-1 in rheumatoid Arthritis and osteoarthritis. Egypt Rheumatol Rehab 30(6):841-860

Arnett FC, Edworthy SM, Bloch DA, McShane DJ, Fries JF, Cooper NS, Healey LA, Kaplan SR, Liang MH, Luthra HS (1988) The American rheumatism association 1987 revised criteria for the classification of rheumatoid arthritis. Arthritis Rheum 31(3):315-324

Bączyk J, Guszczyn T, Romanowicz L, Pancewicz S, Moniuszko A, Popko J (2016) IGF-I and IGF-binding proteins in synovial fluid of patients with Lyme arthritis. Prog Health Sci 6:49-56. https ://doi.org/10.5604/01.3001.0009.5109

Bańkowski E (2016) Biochemia, textbook for students of medical schools. Edra Urban \& Partner 3:228

Beliozon A, Kirman I, Balik E, Karten M, Jain S, Whelan RL (2007) Major surgical trauma induces proteolysis of insulin-like growth factor binding protein-3 in transgenic mice and is associated with a rapid increase in circulating levels of matrix metalloproteinase-9. Surg Endosc 21(4):653-658. https://doi.org/10.1007/ s00464-006-9103-x

Bradford MM (1976) A rapid and sensitive method for quantitation of microgram quantities of protein utilizing the principle of protein-dye binding. Anal Biochem 72:248-254. https://doi. org/10.1016/0003-2697(76)90527-3

Caglič D, Repnik U, Jedeszko C, Kosec G, Miniejew C, Kindermann M, Vasiljeva O, Turk V, Wendt KU, Sloane BF, Goldring MB, Turk B (2010) The proinflammatory cytokines interleukin- $1 \alpha$ and tumor necrosis factor $\alpha$ promote the expression and secretion of proteolytically active cathepsin $\mathrm{S}$ from human chondrocytes. Biol Chem 394(2):307-316. https://doi.org/10.1515/ hsz-2012-0283

Collett-Solberg PF, Cohen P (2000) Genetics, chemistry, and functions of the IGF/IGFBP system. Endocrine 12(2):121-136. https://doi. org/10.1385/ENDO:12:2:121

de Albornoz Torrente M, Forriol F (2012) Changes in synovial fluid in different knee-joint diseases. Rev Esp Cir Ortop Traumatol 56:140-148. https://doi.org/10.1016/j.recote.2012.03.003

De Benedetti F, Meazza C, Oliveri M, Pignatti P, Vivarelli M, Alonzi T, Fattori E, Garrone S, Barreca A, Martini A (2001) Effect of Il-6 on IGF binding protein-3: a study in Il- 6 transgenic mice and in patients with systemic juvenile idiopathic arthritic. Endocrinology 142911:4818-4826. https://doi.org/10.1210/endo.142.11.8511

de Sousa EB, Casado PL, Nato VM, Leite Duarte ME, Aguiar DP (2014) Synovial fluid and synovial membrane mesenchymal stem cells: latest discoveries and therapeutic perspectives. Stem Cell Res Ther 5(5):112. https://doi.org/10.1186/scrt501

Denko CW, Boja B, Moskowitz RW (1996) Growth factors, insulin-like growth factor-1 and growth hormone, in synovial fluid and serum of patients with rheumatic disorders. Osteoarth Cart 4(4):245-249

Dziak A (2001) Precocious wear out syndrome of the articular cartilage. Acta Clin 1:5-8

Forbes BE, McCarthy P, Norton RS (2012) Insulin-like growth factor binding proteins: a structural perspective. Front Endocrinol 3:1-13. https://doi.org/10.3389/fendo.2012.00038

Freeman HC, Smith JEWL, Taylor JC (1961) Crystallographic studies of the biuret reaction. I. Potassium bis-biuret cuprate(II) tetrahydrate, $\mathrm{K} 2[\mathrm{Cu}(\mathrm{NHCONHCONH}) 2] \cdot 4 \mathrm{H}_{2} \mathrm{O}$. Acta Cryst 14:407-418. https://doi.org/10.1107/S0365110X61001339

Giannelli G, Erriquez R, Iannone F, Marinosci F, Lapadula G, Antonaci S (2004) MMP-2, MMP-9, TIMP-1 and TIMP-2 levels in patients with rheumatoid arthritis and psoriatic arthritis. Clin Exp Rheumatol May-Jun 22(3):335-338

Guszczyn T, Rzeczycka J, Popko J (2009) IGF-I and IGF-binding proteins in articular exudates of children with post-traumatic knee damage and juvenile idiopathic arthritis. Pathobiology 76(5):260 266. https://doi.org/10.1159/000228902

Heard BJ, Martin L, Rattner JB, Frank CB, Hart DA, Krawetz R (2012) Matrix metalloproteinase protein expression profiles cannot distinguish between normal and early osteoarthritic synovial fluid. BMC Musculoskelet Disord Jul 23:13:126. https://doi. org/10.1186/1471-2474-13-126

Herchenhan A, Bayer ML, Eliasson P, Magnusson SP, Kjaer M (2015) Insulin-like growth factor I enhances collagen synthesis in engineered human tendon tissue. Growth Horm IGF Res 25(1):13-29. https://doi.org/10.1016/j.ghir.2014.09.001

Hrycaj PZ, Łącki JK (2002) From osteoarthrosis to osteoarthritiscurrent view on the pathogenesis of degenerative joint disease. Nowa Med 2:7-18

Jin T, Tarkowski A, Carmeliet P, Bokarewa M (2003) Urokinase, a constitutive component of the inflamed synovial fluid, induces arthritis. Arthritis Es Ther 5(1):9-17. https://doi.org/10.1186/ar606

Józefiak A, Pacholska J, Kędzia W (2008) Rola IGF-I i IGFBP w procesie neogenezy. Perinat Neonat Ginek 1(3):175-183

Laemmli UK (1970) Cleavage of structural proteins during the assembly of the head of bacteriophage T4. Nature 227:680-685. https ://doi.org/10.1038/227680a0

Malejczyk J (2001) Structure and immunology of the cartilagenous tissue. Acta Clin 1:15-22 
Martin JA, Scherb MB, Lembke LA, Buckwalter JB (2000) Damage control mechanisms in articular cartilage: the role of the insulinlike growth factor I axis. Iowa Orthop J 20:1-11

Masnikosa R, Živković B, Nedić O (2009) IGFBP-1 forms associated with placental cell membranes. J Serb Chem Soc 74(7):707-716

Matsumoto T, Gargosky SE, Iwasaki K, Rosenfeld RG (1996) Identification and characterization of insulin-like growth factors (IGFs), IGF-binding proteins (IGFBPs), and IGFBP proteases in human synovial fluid. J Clin Endocrinol Metab 81(1):150-155. https:// doi.org/10.1210/jcem.81.1.8550744

Mong JLY, Ng MC, Guldan GS, Tam CHT, Lee HM, Ma RCW, So WY, Wong GWK, Kong APS, Chan JCN, Waye MMY (2009) Associations of insulin-like growth factor binding protein-3 gene polymorphisms with IGF-I activity and lipid parameters in adolescents. Int J Obes 33(12):1446-1453. https://doi.org/10.1038/ ijo. 2009.186

Pagura SMC, Thomas SG, Woodhouse LJ, Ezzat S, Marks P (2005) Circulating and synovial levels of IGF-I, cytokines, physical function and anthropometry differ in woman awaiting total knee arthroplasty when compared to men. J Orthop Res 23(2):397-405. https://doi.org/10.1016/j.orthres.2004.08.016

Puche JE, Castilla-Cortàzar I (2012) Human conditions of insulin-like growth factor-I (IGF-I) deficiency. J Transl Med 10:224. https:// doi.org/10.1186/1479-5876-10-224

Rosenzweig SA, Atreya HS (2010) Defining the pathway to insulinlike growth factor system targeting in cancer. Biochem Pharmacol 80(8):1115-1124. https://doi.org/10.1016/j.bcp.2010.06.013

Sapan CV, Lundblad RL, Price NC (1999) Colorimetric protein assay techniques. Biotechnol Appl Biochem 29(Pt 2):99-108. https:// doi.org/10.1111/j.1470-8744.1999.tb00538.x

Schmidt MB, Chen EH, Lynch SE (2006) A review of the effects of insulin-like growth factor and platelet derived growth factor on in vivo cartilage healing and repair. Osteoarth Cart 14(5):403412. https://doi.org/10.1016/j.joca.2005.10.011

Starkman BG, Cravero JD, DelCarlo M, Loese RF (2005) IGF-I stimulation of proteoglycan synthesis by chondrocytes requires activation of the PI 3-kinase pathway but not ERK MAPK. Biochem 389(3):723-729. https://doi.org/10.1042/BJ20041636
Su S, Grover J, Roughley PJ, DiBattista JA, Martel-Pelletier J, Pelletier JP, Zafarullah M (1999) Expression of the tissue inhibitor of metalloproteinases (TIMP) gene family in normal and osteoarthritic joints. Rheumatol Int 18(5-6):183-191

Suwała A, Ziora K, Landowska D (2010) Structure and function of insulin-like growth factors and clinical symptoms of IGF-1 deficiency. Endokrynol Pediatr 3(32):47-61

Tavera C, Abribat T, Reboul P, Doré S, Brazeau P, Pelletier JP, Martel-Pelletier J (1996) IGF and IGF-binding protein system in the synovial fluid of osteoarthritic and rheumatoid arthritic patients. Osteoarth Cart 4(4):263-274. https://doi.org/10.1016/S1063 -4584(05)80104-9

Unemori EN, Werb Z (1989) Reorganization of polymerized actin: a possible trigger for induction of procollagenase in fibroblasts cultured in and on collagen gels. J Cell Biol 103(3):1021-1031. https://doi.org/10.1083/jcb.103.3.1021

Wright RW (2014) Osteoarthritis classification scales, interobserver reliability and arthroscopic correlation. J Bone Joint Surg Am 96(14):1145-1151. https://doi.org/10.2106/JBJS.M.00929

Yoshihara Y, Nakamura H, Obata K, Yamada H, Hayakawa T, Fujikawa K, Okada Y (2000) Matrix metalloproteinases and tissue inhibitors of metalloproteinases in synovial fluids from patients with rheumatoid arthritis or osteoarthritis. Ann Rheum Dis Jun 59(6):455-461

Zaga-Clavellina V, Garcia-Lopez G, Flores-Pliego A, MerchantLarios H, Vadillo-Ortega F (2011) In vitro secretion and activity profiles of matrix metalloproteinases, MMP-9 and MMP-2, in human term extra-placental membranes after exposure to Escherichia coli. Reprod Biol Endocrinol Jan 25:9:13. https:// doi.org/10.1186/1477-7827-9-13

Publisher's Note Springer Nature remains neutral with regard to jurisdictional claims in published maps and institutional affiliations. 